\title{
Influence of cervical preflaring on apical transportation in curved root canals instrumented by reciprocating file systems
}

Neisiana Barbieri, Denise Piotto Leonardi, Marina Samara Baechtold, Gisele Maria Correr, Marilisa Carneiro Leão Gabardo, João César Zielak and Flares Baratto-Filho

\begin{abstract}
Background: The aim of this study was to evaluate the influence of cervical preflaring on apical transportation in curved root canals prepared using the Reciproc and WaveOne reciprocating file systems.

Methods: Sixty curved canals were instrumented using Reciproc R25 and WaveOne Primary files, with and without preflaring $(n=15)$. A double-digital technique was used to digitally superimpose the file before instrumentation (\#15 K-file) on the final apical reciprocating file (\#25/08). The angle between the tip of the initial and final file was measured and recorded. Groups were compared using the Kruskal-Wallis test, and significance was set at $p<0.05$.

Results: The mean and standard deviation for apical transportation was $0.93 \pm 2.48$ for the Reciproc Group, $0.84 \pm 1.94$ for the Preflaring + Reciproc Group, $0.40 \pm 1.14$ for the WaveOne Group, and $0.83 \pm 2.20$ for the Preflaring + WaveOne Group. No statistically significant differences were found among the groups $(p=0.9509)$.

Conclusions: Under the conditions of this study, cervical preflaring did not influence apical transportation in curved root canals instrumented using Reciproc R25 and the WaveOne Primary files. Based on the in vitro measurements of apical transportation, the reciprocating files may be used without preflaring in curved root canals.
\end{abstract}

Keywords: Apical transportation, Reciprocating motion, Root canal preparation, WaveOne

\section{Background}

To reduce infection and to prevent or treat apical periodontitis, it is important that the root canal is mechanically shaped using a technique that cleans and preserves its original anatomy without deviations such as ledging and apical transportation [1,2]. Errors in this procedure hamper efficient cleaning of the root canals, leading to the retention of infected debris and residual microorganisms. Incorrect mechanical shaping can also result in decreased fracture resistance of the root, which may compromise the treatment outcome [3].

Apical transportation is often caused by mechanical instrumentation with large files that are more effective in removing infected tooth structure than small files $[4,5]$. Enlarging the root canal to a larger diameter removes

\footnotetext{
* Correspondence: dpleonardi@gmail.com

Department of Dentistry, Positivo University, Curitiba, Rua Professor Pedro Viriato Parigot de Souza, 5300 Campo Comprido, 81280-330 Curitiba, PR,
} Brazil

more debris and promotes better cleaning of the apical third, while allowing maximal contact of the irrigant with the apical debris [6, 7]. Therefore, mechanical preparation of curved root canals remains challenging [8].

Nickel titanium (NiTi) rotary instruments reduce working time, operator fatigue, and procedural errors during preparation [9]. Owing to their specific design and flexibility, NiTi rotary files make root canal preparation safer and more efficient because they provide better centering in the canal when compared with A recently developed concept of root canal preparation aims to reduce working time and the incidence of fracture by using a single file under a reciprocating motion [13, 14]. Different reciprocating systems have different design features such as taper, depth of flutes, 
cross-sectional design, and number of spirals per unit length. The ability to shape curved root canals without causing apical transportation may be affected by these systems' characteristics [15].

Studies show that the anatomy of the root canal may be modified when shaped by reciprocating systems. Thus, additional technical clinical procedures may be needed $[16,17]$. It is known that cervical preflaring allows a more straight-line access into the root canal, improving the apical anatomical diameter determination $[18,19]$. Moreover, apical transportation may be reduced in root canals that have been preflared [20].

Considering these findings, the present study aimed to evaluate the influence of cervical preflaring on apical transportation in curved root canals prepared using Reciproc R25 and WaveOne Primary file systems.

\section{Methods}

This research has been conducted in full accordance with the World Medical Association Declaration of Helsinki and was approved by the Local Ethics Committee of the Positivo University, Brazil (43104/2012). Teeth used in this study were extracted by periodontal reasons. All pacients have consented the treatment by writing. Sixty mesiobuccal root canals of maxillary molars with complete root formation were selected. Only mesiobuccal (MB) root canals that allowed the placement of a \#10 K-Flexofile (Dentsply Maillefer, Ballaigues, Switzerland) to the apical foramen were used. Access cavities were prepared with round diamond and Endo-Z burs (Dentsply). The working length (WL) of each canal was established by inserting a \#10 K-Flexofile into the root canal until the file tip became visible through the apical foramen under a stereomicroscope at $20 \times$ magnification, then subtracting $1 \mathrm{~mm}$.

An apparatus was manufactured in acrylic resin to provide a fixed position for the digital dental X-ray sensor and cone alignment. A \#15 K-Flexofile was inserted into the root canal at the WL and a digital radiograph (Kodak RVG 6100; Kodak, Rochester, NY, USA) was obtained to register the initial apical curvature. The root canal curvature angle and radius were measured according to the method of Pruett et al. [21] using the AutoCAD 2008 program (Autodesk Inc, San Rafael, CA, USA). The samples were divided into four groups $(n=15)$ with similar canal lengths, angles, and radii of curvature. The angles of curvature ranged from $20^{\circ}$ to $40^{\circ}$ and the radius $6 \mathrm{~mm}$.

A double-digital radiographic technique was used to analyze apical transportation [15]. Two preinstrumentation digital radiographs with buccolingual and mesiodistal views were obtained of each tooth with a \#15 K-Flexofile at the WL.

Group 1 was assigned to preparation with Reciproc \#25.08 (VDW GmbH, Munich, Germany) at the WL. Group 2 was assigned to cervical preflaring with SX
(Dentsply Maillefer) and preparation with Reciproc \#25.08 at the WL. Group 3 was assigned to preparation with WaveOne \#25.08 (Dentsply Maillefer) at the WL. Group 4 was assigned to cervical preflaring with SX (Dentsply Maillefer) and preparation with WaveOne \#25.08 (Dentsply Maillefer) at the WL.

The instruments were activated with a 6:1 reduction hand piece powered by a torque-limited electric motor (X-Smart Plus, Dentsply Maillefer) using the preset program Reciproc for the Reciproc instruments and the preset program WaveOne for the WaveOne instruments. SX instruments were used with the same electric motor using the preset program for the SX instrument. A glide path up to \#15 Flexofile was set before instrumentation. The root canals were irrigated with $5.25 \% \mathrm{NaOCl}$ delivered with a syringe and a 30 -gauge side-vented irrigating tip.

Reciprocating files were gradually inserted into the root canal with cycles of three pecks, removed and cleaned, and the root canal was irrigated. Each instrument was used in four root canals. After preflaring, reciprocating files WL was repositioned in $1 \mathrm{~mm}$ from the root apex when it was observed working length changes. When preparation was complete, the \#25.08 Reciproc or WaveOne file was placed into the root canal at the WL, the tooth was repositioned on the radiographic apparatus, and two post-instrumentation radiographs were taken.

Adobe Photoshop software (Adobe Systems Inc., San Jose, CA, USA) was used to superimpose each post-instrumentation image onto its matching preinstrumentation image. The images were imported into the freely available ImageJ software (http://imagej.nih.gov/ ij/) to analyze the apical transportation. The angle between the tip of the initial and final file was measured and the higher value (buccolingual or mesiodistal) was recorded (Fig. 1).

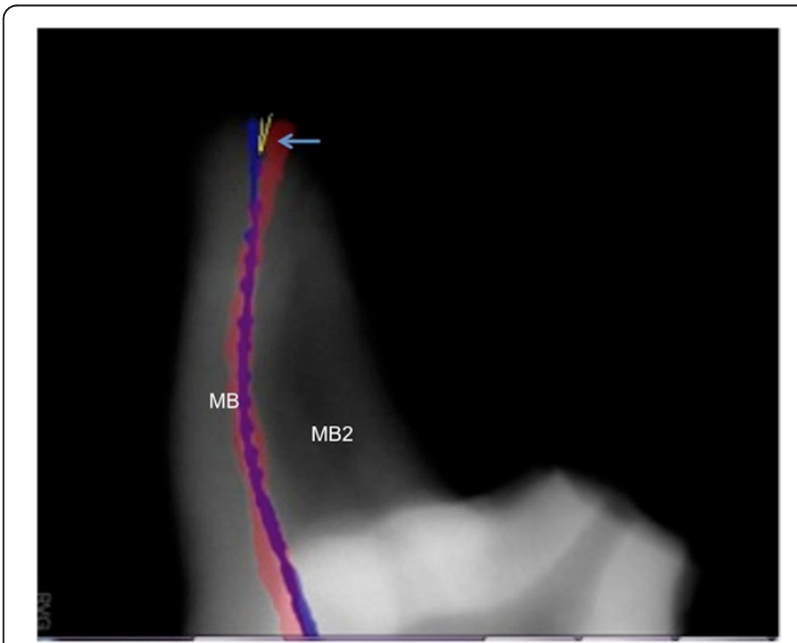

Fig. 1 Angle between the tip of the initial and final file (arrow) 
Data were evaluated for normal distribution using the Kolmogorov-Smirnov and Lilliefors test. Homogeneity was analyzed using the Levene test. Since the data did not follow a normal distribuition the groups were compared using the non-parametric Kruskal-Wallis test. Significance was set at $p<0.05$ (Statistica 7.0, Statsoft, 2004).

\section{Results}

The mean and standard deviation of the angle between the tip of the initial and final files were $0.93^{\circ} \pm 2.48^{\circ}$ in the Reciproc Group, $0.84^{\circ} \pm 1.94^{\circ}$ in the Preflaring + Reciproc Group, $0.40^{\circ} \pm 1.14^{\circ}$ in the WaveOne Group, and $0.83^{\circ} \pm$ $2.20^{\circ}$ in the Preflaring + WaveOne Group. The KruskalWallis test showed no statistically significant differences among the groups $(p=0.9509)$.

\section{Discussion}

The single-file principle for root canal preparation has advantages of ease of learning and cost effectiveness [22]. Yared [23] introduced this technique using the ProTaper F2 instrument in a reciprocating motion.

Two further root canal preparation systems were introduced featuring reciprocating motion: Reciproc (VDW) and WaveOne (Dentsply Maillefer). These instruments are made of $\mathrm{M}$-wire NiTi alloy produced by an innovative thermal treatment process [24]. Both instruments were designed to promote improved shaping, lower the rate of instrument failure, and reduce the number of procedural steps. Recently, there is a new generation of reciprocating file, the WaveOne GOLD whose design has also been optimized to increase cutting efficiency.

Apical transportation may reduce root canal disinfection and difficult sealing ability of the root filling [25]. Studies have assessed apical transportation in curved root canals prepared with reciprocating instruments [26-29]. However, the effect of cervical preflaring when using Reciproc and WaveOne instruments has not been assessed.

In our study, apical transportation was minimal in all groups even when cervical preflaring was not performed. This may be due to the initial width of the root canal in which a \#10 K-file was easily inserted. Maybe if the initial root canal width was smaller the preflaring procedure could have shown effects on the apical transportation. There were no differences between WaveOne and Reciproc groups with no preflaring. Previous studies obtained similar results when using reciprocating instruments in curved canals assessed by similar radiographic techniques $[17,30]$. Furthermore, no differences between the two reciprocating systems have been observed in studies using different techniques [16, 31]. Radiographic superimposition techniques are frequently used to assess apical transportation. Despite the inability to achieve a volumetric analysis, the radiographic method is inexpensive, easy to perform, and reliable [32]. In this present study, each sample was positioned on the radiographic apparatus in order to achieve standardized radiographic images and to reduce errors.

The results from our study may be related to the characteristics of the instruments. The Reciproc R25 and the WaveOne Primary have a size 25 non-cutting tip with a taper of 0.08. Non-cutting tips have been shown to produce apical transportation in severely curved canals [33]. Thus, taper size plays an important role in apical transportation: the larger the taper of the instrument, the lower is its flexibility [34]. However, in root canals with apical curvature ranging from $20^{\circ}$ to $40^{\circ}$, these instruments may be able to retain their original conformation. Similar results were observed in a study by Capar et al. [16], who assessed apical transportation in curvatures ranging from $20^{\circ}$ to $40^{\circ}$ using R25 and WaveOne Primary files.

Besides, the results may be also related to the instrument movement. Reciprocation motion occurs in the direction of the flutes, which are ground angled to the left, being the opposite of balanced force movement kinematics [35, 36]. As previously stated, the reciprocating movement aims to minimize the risk of instrument fracture caused by torsional stress once the angle of the counterclockwise rotation is designed to be smaller than the elastic limit of the instrument [22]. A smaller angle in a clockwise direction allows the file to be immediately disengaged and safely progress along the canal path, while reducing the screwing effect. These conditions raise questions about the influence of this movement on apical transportation. Giuliani et al. [37] observed when preparing S-shaped canals that full-sequence ProTaper Universal NiTi files used in a reciprocating motion exhibited better shaping effects than full-sequence ProTaper Universal NiTi files used in a conventional motion.

The results of any in vitro study must be carefully applied to the clinical practice. From our data, it can be conclude that cervical preflaring did not influence the occurrence of apical transportation when curved root canals were prepared with Reciproc R25 and WaveOne Primary files. Both Reciproc R25 and WaveOne Primary file systems performed similarly in curved root canals.

\section{Abbreviations}

NiTi: Nickel titanium; WL: Working length.

\section{Competing interests}

The authors declare that they have no competing interests.

\section{Authors' contributions}

NB performed the root canal preparation and the data analysis. DPL designed the article, supervised the experiment and helped to draft the article. MSB performed the literature research. GMC performed the data analysis. MCLG performed the selection of the teeth and the literature research. JCZ helped to draft the article. FBF designed the article and revised the final version of the text. All authors read and approved the final manuscript. 
Received: 25 May 2015 Accepted: 17 November 2015

Published online: 23 November 2015

\section{References}

1. Schilder H. Cleaning and shaping the root canal. Dent Clin North Am. 1974;18:269-96.

2. Baugh D, Wallace J. The role of apical instrumentation in root canal treatment: a review of the literature. J Endod. 2005;31:333-40.

3. Schäfer E, Dammascke T. Development and sequelae of canal transportation. Endod Topics. 2009;15:75-90.

4. Shuping GB, Ørstavik D, Sigurdsson A, Trope M. Reduction of intracanal bacteria using nickel-titanium rotary instrumentation and various medications. J Endod. 2000;26:751-5.

5. Card SJ, Sigurdsson A, Ørstavik D, Trope M. The effectiveness of increased apical enlargement in reducing intracanal bacteria. J Endod. 2002;28:779-83.

6. Siqueira Jr JF, Lima KC, Magalhães FA, Lopes HP, de Uzeda M. Mechanical reduction of the bacterial population in the root canal by three instrumentation techniques. J Endod. 1999;25:332-5.

7. Ram Z. Effectiveness of root canal irrigation. Oral Surg Oral Med Oral Pathol. 1977:44:306-12.

8. Weine F, Kelly R, Lio P. The effect of preparation procedures on original canal shape and on apical foramen shape. J Endod. 1975;1:262-6.

9. Gluskin AH, Brown DC, Buchanan LS. A reconstructed computerized tomographic comparison of Ni-Ti Rotary GT files versus traditional instruments in canals shaped by novice operators. Int Endod J. 2001;34:476-84

10. Schäfer E, Lohmann D. Efficiency of rotary nickel-titanium FlexMaster instruments compared with stainless steel hand K-Flexofile. Part 1. Shaping ability in simulated curved canals. Int Endod J. 2002;35:505-13.

11. Schirrmeister JF, Strohl C, Altenburger MJ, Wrbas KT, Hellwig E. Shaping ability and safety of five different rotary nickel-titanium instruments compared with stainless steel hand instrumentation in simulated curved root canals. Oral Surg Oral Med Oral Pathol Oral Radiol Endod. 2006;101:807-13.

12. Haïkel Y, Serfaty R, Bateman G, Senger B, Allemann C. Dynamic and cyclic fatigue of engine-driven rotary nickel-titanium endodontic instruments. J Endod. 1999;25:434-40.

13. You SY, Bae KS, Baek SH, Kum KY, Shon WJ, Lee W. Lifespan of one nickel-titanium rotary file with reciprocating motion in curved root canals. J Endod. 2010;36:1991-4.

14. De-Deus G, Moreira EJ, Lopes HP, Elias CN. Extended cyclic fatigue life of F2 ProTaper instruments used in reciprocating movement. Int Endod J. 2010;43:1063-8.

15. Duran-Sindreu F, García M, Olivieri JG, Mercadé M, Morelló S, Roig M. A comparison of apical transportation between FlexMaster and Twisted Files rotary instruments. J Endod. 2012;38:993-5.

16. Capar ID, Ertas H, Ok E, Arslan H, Ertas ET. Comparative study of different novel nickel-titanium rotary systems for root canal preparation in severely curved root canals. J Endod. 2014;40:852-6.

17. Bürklein S, Hinschitza K, Dammaschke T, Schäfer E. Shaping ability and cleaning effectiveness of two single-file systems in severely curved root canals of extracted teeth: Reciproc and WaveOne versus Mtwo and ProTaper. Int Endod J. 2012;45:449-61.

18. Pecora JD, Capelli A, Guerisoli DM, Spanó JC, Estrela C. Influence of cervical preflaring on apical file size determination. Int Endod J. 2005;38:430-5.

19. Tan BT, Messer HH. The effect of instrument type and preflaring on apical file size determination. Int Endod J. 2002;35:752-8.

20. Fogarty TJ, Montgomery S. Effect of preflaring on canal transportation. Evaluation of ultrasonic, sonic, and conventional techniques. Oral Surg Oral Med Oral Pathol. 1991;72:345-50.

21. Pruett JP, Clement DJ, Carnes Jr DL. Cyclic fatigue testing of nickel titanium endodontic instruments. J Endod. 1997;23:77-85

22. Plotino G, Grande NM, Testarelli L, Gambarini G. Cyclic fatigue of reciproc and wave one reciprocating instruments. Int Endod J. 2012:45:614-8.

23. Yared G. Canal preparation using only one Ni-Ti rotary instrument: preliminary observations. Int Endod J. 2008:41:339-44

24. Gambarini G, Grande NM, Plotino G, Somma F, Garala M, De Luca M, et al. Fatigue resistance of engine-driven rotary nickel-titanium instruments produced by new manufacturing methods. J Endod. 2008;34:1003-5.
25. Wu MK, Fan B, Wesselink PR. Leakage along apical root fillings in curved root canals. Part I: effects of apical transportation on seal of root fillings. J Endod. 2000;26:210-6.

26. Bürklein S, Benten S, Schäfer E. Shaping ability of different single-file systems in severely curved root canals of extracted teeth. Int Endod J. 2013;46:590-7.

27. Marceliano-Alves MF, Sousa-Neto MD, Fidel SR, Steier L, Robinson JP, Pécora JD et al. Shaping ability of single-file reciprocating and heat-treated multifile rotary systems: a micro-CT study. Int Endod J. 2014;14. in press.

28. Lim YJ, Park SJ, Kim HC, Min KS. Comparison of the centering ability of Wave one and reciproc nickel-titanium instruments in simulated curved canals. Restor Dent Endod. 2013;38:21-5.

29. Wu H, Peng C, Bai Y, Hu X, Wang L, Li C. Shaping ability of ProTaper Universal waveone and ProTaper Next in simulated L-shaped and S-shaped root canals. BMC Oral Health. 2015;15:27.

30. Saber SE, Nagy MM, Schäfer E. Comparative evaluation of the shaping ability of waveone, reciproc and oneshape single-file systems in severely curved root canals of extracted teeth. Int Endod J. 2015;48:109-14.

31. Gergi R, Arbab-Chirani R, Osta N, Naaman A. Micro-computed tomographic evaluation of canal transportation instrumented by different kinematics rotary nickel-titanium instruments. J Endod. 2014;40:1223-7.

32. Ounsi HF, Franciosi G, Paragliola R, Al-Hezaimi K, Salameh Z, Tay FR, et al. Comparison of two techniques for assessing the shaping efficacy of repeatedly used nickel-titanium rotary instruments. J Endod. 2011;37:847-50.

33. Schäfer $E$. Effect of four instrumentation techniques on curved canals: a comparison study. J Endod. 1996:22:685-90.

34. Javaheri $\mathrm{HH}$, Javaheri $\mathrm{GH}$. A comparison of three $\mathrm{Ni}-\mathrm{Ti}$ Rotary instruments in apical transportation. J Endod. 2007;33:284-6.

35. Paque F, Zehnder M, De-Deus G. Microtomography-based comparison of reciprocating single-file F2 ProTaper technique versus rotary full sequence. J Endod. 2011;37:1394-7.

36. De-Deus G, Neves A, Silva EJ, Mendonça TA, Lourenço C, Calixto C, et al. Apically extruded dentin debris by reciprocating single-file and multi-file rotary system. Clin Oral Investig. 2015;19:357-61.

37. Giuliani V, Di Nasso L, Pace R, Pagavino G. Shaping ability of waveone primary reciprocating files and ProTaper system used in continuous and reciprocating motion. J Endod. 2014;40:1468-71.

\section{Submit your next manuscript to BioMed Central and we will help you at every step:}

- We accept pre-submission inquiries

- Our selector tool helps you to find the most relevant journal

- We provide round the clock customer support

- Convenient online submission

- Thorough peer review

- Inclusion in PubMed and all major indexing services

- Maximum visibility for your research

Submit your manuscript at www.biomedcentral.com/submit 